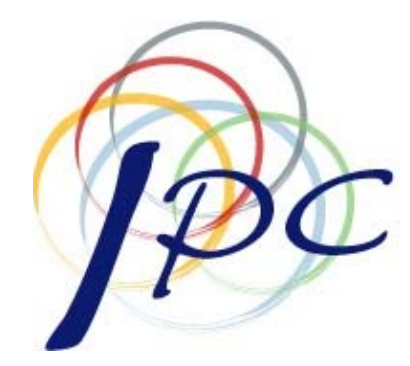

International Policy Center

Gerald R. Ford School of Public Policy University of Michigan

IPC Working Paper Series Number 4

The Responsibility Paradox:

Multinational Firms and Global Corporate Social Responsibility

\author{
Gerald F. Davis \\ Marina von Neumann Whitman
}

Mayer N. Zald

November 2005 


\title{
The Responsibility Paradox: Multinational Firms and Global Corporate Social Responsibility*
}

\author{
Gerald F. Davis \\ Stephen M. Ross School of Business, The University of Michigan \\ gfdavis@umich.edu \\ Marina von Neumann Whitman \\ Gerald R. Ford School of Public Policy and Stephen M. Ross School of Business,, \\ The University of Michigan \\ marinaw@umich.edu \\ Mayer N. Zald \\ Department of Sociology, The University of Michigan \\ mayerz@umich.edu
}

RUNNING HEAD: MNCs and Corporate Social Responsibility

* We thank David Hess, Sid Tarrow, and participants in the "Global Corporation and Human Well-Being” seminar for comments, and the Center for Advancing Research and Solutions for Society for funding. 


\section{Abstract}

This paper examines the impact of multinational firms’ increasingly blurred geographical and institutional boundaries on the nature and definition of Corporate Social Responsibility (CSR). It begins with a brief history of CSR, describes changes in the global corporation and the pressures impinging on it over the past 25 years, and analyzes the resulting mismatch between the contemporary corporation and traditional concepts of CSR. It then dissects some of the issues raised by this new concept of CSR, and speculates on future trajectories for CSR in multinational corporations as globalization continues to exert pressure for convergence of national standards into a more universal definition of Global CSR. 
Discussions of corporate social responsibility typically are premised on a view of the corporation as a social actor, comprised of members and located in a tangible place. They have stakeholders—employees, investors, suppliers, consumers, and broader communities—each of which is owed a particular responsibility. Debates often turn on which stakeholders are primary (shareholders, employees, or a broader community), or whether CSR activities, such as supporting the local non-profit community, yield positive performance benefits for the organization (Margolis and Walsh, 2003). In this paper, we argue that CSR (understood as actions a company takes that are not legally mandated but are intended to have a positive impact on stakeholders, broadly construed) is challenged by the changing shape of the contemporary multinational corporation. ${ }^{\mathrm{i}}$ Global companies today are often characterized as mere legal fictions that act as a center for the coordination of contractual relations, from supply chains and distribution channels to financial arrangements and licensing agreements. Moreover, their legal and headquarters locales often bear little relation to the places where their goods and services are produced or delivered. They are "rootless cosmpolitans," in Martin Wolf’s (2004) paraphrase. Thus, obligations to their “employees” or “communities” are a conundrum.

We therefore introduce and unpack the concept of "global corporate social responsibility.” While firms traditionally orient their CSR activities (such as philanthropy and employee voluntarism) toward local communities, particularly their headquarters city, global CSR implies that corporations may be held responsible for actions beyond the firm's boundaries and beyond their local community to include suppliers, distributors, alliance partners, and even sovereign nations in which they do business. We begin with a brief history of CSR, describe some of the changes in the global corporation over the past 25 years, and analyze the mis-match between the contemporary corporation and traditional ideas of CSR. We discuss new pressures 
on the global corporation arising from competition in product markets, demands from capital markets, and regulatory and social pressures that follow from global operations. We then dissect some of the issues raised by this new concept of CSR, and speculate on future trajectories for CSR in global corporations.

\section{Origins of Corporate Social Responsibility}

Corporate social responsibility (CSR) is, at least in its naming and formal recognition, a relatively recent phenomenon. Yet owners and managers of firms have engaged in activities that we would now consider CSR almost from the beginning of the industrial revolution. Programs today regarded as "extra-curricular" were integral to production in the late $18^{\text {th }}$ century, as the industrial revolution concentrated production in factories. Societal institutions for the support of factory work were under-developed at that time: both the physical and social infrastucture for large-scale manufacturing were lacking. Thus, owners found that they had to provide for the efficient transport of raw materials and products and the housing, education, and literacy of workers. Moreover, they found workers to be lacking in labor discipline: they were slothful, prone to drunkenness, unused to punctuality, and in general difficult to manage (Pollard, 1965).

For some of these problems, entrepreneurs could court support from the relevant governmental level, but they often had to rely on their own resources. Business owners often helped develop roads and canals, and they supported other groups interested in issues such as education of workers and their children. If the factory did not have a suitable stock of housing nearby, factory owners might build housing estates. Moreover, owners saw advantages for supporting "moral education" in support of labor discipline. Inside the factory, owners could use rewards and punishments to induce what they saw as proper behavior, such as punctuality and attentiveness to quality. But owners also provided support for the efforts of churches and 
evangelists to change the moral codes of laborers outside the workplace. Thus, the early industrial revolution was a period of great religious ferment, and working class communities proved fertile ground for religious cultivation.

When roads and canals became the province of the state, or when companies emerged to provide transportation services, manufacturers stopped supplying them. When plants were located in urban areas, the need to provide housing declined. But well into the late nineteenth century, owners often provided housing and community services, sometimes with beneficent motivations, sometimes with a strong control and discipline component. Pullman, Illinois, a company town created on the edge of Chicago to service the manufacture of railroad cars, led a contemporary commentator to state: "The wholesome, cheerful surroundings enable the men to work more constantly and more efficiently” (Richard Ely, “Pullman: A Social Study,” Harper’s Magazine 70: 452-466, 1885). But he went on to note the downside of a company-run total institution: "It is benevolent, well wishing feudalism, which desires the happiness of the people, but in such way as shall please the authorities," and Pullman went on to be the site of one of the most famous and brutal labor disputes in US history in 1894. (Company towns still feature prominently in some developing economies; e.g., the Tata conglomerate in India continues to operate the town of Jamshedpur on behalf of its steel manufacturing facility.)

The creation of the great fortunes of the late 19th and early 20th centuries spurred a wave of extra-local philanthropy that might be considered a forerunner of CSR. John Rockefeller provided the funds for creating the University of Chicago, and Andrew Carnegie was instrumental in funding public libraries in many communities across the country, far from the origins of his steel fortune. Realizing that the meager salaries of college faculty at the time left 
them without adequate resources for their retirement years, Carnegie also provided the funds to begin TIAA, which became the major vehicle for faculty pension support in the United States. By the beginning of the 20th century "welfare capitalism" became the name of those activities in which companies provided extensive community facilities and company programs to their workers. Sometimes done with a real commitment to the workers and their families, other times with an eye on keeping labor unions out or under the control of management and keeping the state at arm's length, welfare capitalism became widespread. From community activities to medical services and retirement plans, American firms provided what increasingly became the province of the state in Europe. Of course, the range of services and programs varied enormously and most of the population was not employed by these firms, but even during and after the Great Depression, many firms continued to engage in these practices, often to forestall unionization attempts (Jacoby, 1997).

During the post-World War II era, employee health insurance and pension programs that embodied the essence of welfare capitalism became standard practice in large corporations as components of modern human resource management. However, externally-oriented CSR programs became more problematic, as a debate emerged about how much responsibility firms had for their communities. If the expenditures were not aimed at improving profits, were they justifiable? The Michigan Supreme Court's decision in Dodge v. Ford Motor in 1919 had stated it plainly: "A business corporation is organized and carried on primarily for the profit of the stockholders. The powers of the directors are to be employed for that end. The discretion of directors is to be exercised in the choice of means to attain that end, and does not extend to a change in the end itself, to the reduction of profits, or to the non-distribution of profits among stockholders in order to devote them to other purposes.” How could one distinguish between 
philanthropy aimed at satisfying the major owner's or CEO’s personal tastes and a more articulated formulation of how the corporation should relate to its surrounding communities? Responses to these questions went back to the writings of Maurice Clark in the first twenty five years of the 20th century, and continued in the writings of academics such as Clarence Walton and Howard Bowen. Indeed, Archie Carroll (1999) attributes the modern conception of corporate social responsibility to Howard R. Bowen's landmark book, Social Responsibilities of the Businessman (1953). Others might dispute that attribution, but it is clear that in the 1950s more academic attention was paid to issues of business social responsibility.

It is useful to consider what contemporary commentators had in mind at this time when they wrote about the corporation. Carl Kaysen (1957: 313-4) famously coined the phrase "the soulful corporation" to refer to the new, more "responsible" large enterprise: "No longer the agent of proprietorship seeking to maximize return on investment, management sees itself as responsible to stockholders, employees, customers, the general public, and, perhaps most important, the firm itself as an institution.” Dispersed ownership and the availability of oligopoly profits enabled “a variety of expenditures whose benefits are broad, uncertain, and distant” (315), directed by a public-spirited cadre of professional managers. Moreover, "The whole labor force of the modern corporation is, insofar as possible, turned into a corps of lifetime employees, with great emphasis on stability of employment” (312) and thus "Increasingly, membership in the modern corporation becomes the single strongest social force shaping its career members...” (318).

Corporations were therefore powerful social institutions with enormous potential as levers of public policy. Thus, while prior efforts at Federal regulation of the corporation focused primarily on antitrust and investor protection, regulation beginning in the 1960s began to treat 
the corporation as an instrument of social policy aimed at eliminating discrimination, creating safer products and workplaces, and improving environmental quality. Through the channel of Federal regulation, social movements thereby began to influence corporate practice. The Civil Rights Act of 1964 established the Equal Employment Opportunity Commission to eliminate illegal workplace discrimination, and the Equal Employment Opportunity Act of 1972 gave the EEOC litigation authority. In the subsequent year, the EEOC created task forces to investigate discriminatory employment practices at "soulful corporations” such as Ford, Sears, GE, and GM, resulting in "affirmative remedies" for women and minorities going forward. Other movements built on the example of the Civil Rights movement in the late 1960s. Indeed, the Nixon Administration presided over perhaps the most sustained regulatory effort at ameliorating the social impact of the corporation in US history, with the creation of the Environmental Protection Agency in 1970, the passage of the Occupational Safety and Health Act of 1970, and the establishment of the Consumer Product Safety Commission in 1972 (Whitman, 1999).

Due in part to the impact of social movements on Federal policy, what had been the corporation's spontaneous beneficence toward its various stakeholders became encoded in regulation and statute. Indeed, one of the lasting impacts of these regulations is that the industries with the best overall records in a particular domain of social impact tend to be those that have historically been most heavily regulated or otherwise subject to social pressures. To document this observation, we calculated the average score by industry for three of the domains of social impact rated by KLD Research \& Analytics. KLD’s Socrates database provides annual ratings of several hundred public corporations on multiple dimensions of social responsibility for use by the "socially responsible investment" industry (see http://www.kld.com/). We find that the top-rated industries for our first dimension, “community engagement,” were financial 
institutions whose contributions are effectively mandated by the Community Reinvestment Act of 1977. The top industries with respect to "environment," the second dimension, were petroleum refining, primary metals, rubber/plastic, and utilities (electric and gas), all susceptible to EPA oversight. Finally, the top industries for employment practices were primary metal, airlines, petroleum refining, and transportation, i.e., those among the most heavily unionized. ${ }^{\text {ii }}$ Thus, while the literature on CSR typically highlights anecdotal evidence of corporate altruism (e.g., the oft-repeated story of Merck’s development of its river blindness drug—see Margolis and Walsh 2003 for a critique), our reading suggests that regulation may be a surer path to soulful corporate behavior than good-hearted executives. (On the other hand, T.J. Rodgers, CEO of Cypress Semiconductor, responded to efforts by the Clinton Administration to induce more corporate good works with an op-ed in the New York Times (April 29, 1997): "When good works cease to be voluntary and become compulsory, charity becomes confiscation and freedom becomes servitude. Philanthropy is a byproduct of wealth, and wealth is best created in free markets whose workings embody a fundamental and true moral principle long forgotten in Washington.”)

As Federal policy codified more explicitly the social responsibilities of the corporation, academics and consultants increasingly promoted social audits that represented an institutionalized attempt to measure social performance. Some corporations began to systematically study and report on their own practices; GM, for instance, published its first Public Interest Report in 1972, and by 2005 52\% of the Fortune Global 250 largest firms produced corporate responsibility reports separate from their annual financials, of which $30 \%$ were independently verified, usually by accounting firms (KPMG International Survey of Corporate Responsibility Reporting 2005). Stock mutual funds were founded that traded only in 
shares of firms meeting social responsibility criteria, such as the Pax World Fund, launched in 1971. From 1995 to 1999, funds investing in “socially screened” firms increased from \$162 billion to $\$ 1.5$ trillion in assets-about $1 / 8^{\text {th }}$ of the US mutual fund industry (Fung, O’Rourke, and Sabel, 2001). Investor activism increased as more proxy resolutions were introduced by both individuals and activist funds to prompt more ethical corporate action (Proffitt, 2001).

The growing interest in CSR created a demand for assessment tools to rate CSR and for professional groups to establish and promote CSR standards and practices. Reporting services developed to evaluate the efforts of corporations to promote CSR. Moreover, whereas owners and chief executives had set the policies for corporate philanthropy in earlier times without necessarily having a business rationale for their allocations, corporations began to rationalize their practices to fit senior managers’ understandings of the duties and strategic requirements attached to the new normative standards. CSR was becoming an institution to deal with “stakeholder management,” much as human resource management was institutionalized as a field and profession to manage employment relations (Dobbin and Sutton, 1998).

\section{The Changing Shape of the Multinational Enterprise}

Both the concept and the implementation of CSR followed multinational corporations in becoming increasingly global during the final decades of the twentieth century. In the process, two important kinds of boundaries became increasingly fuzzy: corporate boundaries that mark the distinction between activities and transactions occurring "inside” as opposed to "outside” a corporate entity, and national boundaries that separate "domestic" from "foreign." And these developments have caused significant shifts in the way companies and their various constituencies regard CSR. Traditional CSR takes the hierarchical, integrated domestic manufacturer described by Kaysen as the prototype, available as a tool of social policy to 
regulators in Washington and social activists. But the multinational enterprise of the $21^{\text {st }}$ century bears little resemblance to its forbears, rendering the question of to whom it is responsible problematic.

\subsection{Eroding Corporate Boundaries}

Commentators in the 1950s and 1960s, such as Kaysen (1957), described continuous growth as the paramount objecitve of the corporation. One expected result was that the corporate sector would become ever larger, more concentrated, and more integrated over time, with a handful of the more "soulful" or beneficent corporations occupying dominant positions at the core of the economy. The emergence of acquisitive conglomerates in the 1960s and 1970s added the likes of ITT and Gulf + Western to the ranks of the largest firms, further concentrating corporate assets. But de-regulation in the 1980s enabled a wave of bust-up takeovers, followed by a trend toward vertical dis-integration and outsourcing that gained momentum during the 1990s. The result was that corporations were relatively smaller and more focused on a narrow range of activities within their corporate boundaries. Employment was becoming less concentrated in large firms, and the average number of industries in which a Fortune 500 manufacturing firm operated shrank rapidly between the mid-1980s and the end of the century (see Figures 1 and 2 below). Indeed, by the turn of the century, a number of large “manufacturing” firms were in fact manufacturing nothing at all. Companies like Sara Lee sold off nearly all their manufacturing plants and became, in essence, “virtual” manufacturers, taking charge of design, marketing, and distribution but outsourcing the actual manufacturing to suppliers, following a model pioneered by Nike. 
Figure 1: Declining employment concentration

\section{Largest 500 Companies Share of Private Sector Employment (\%)}

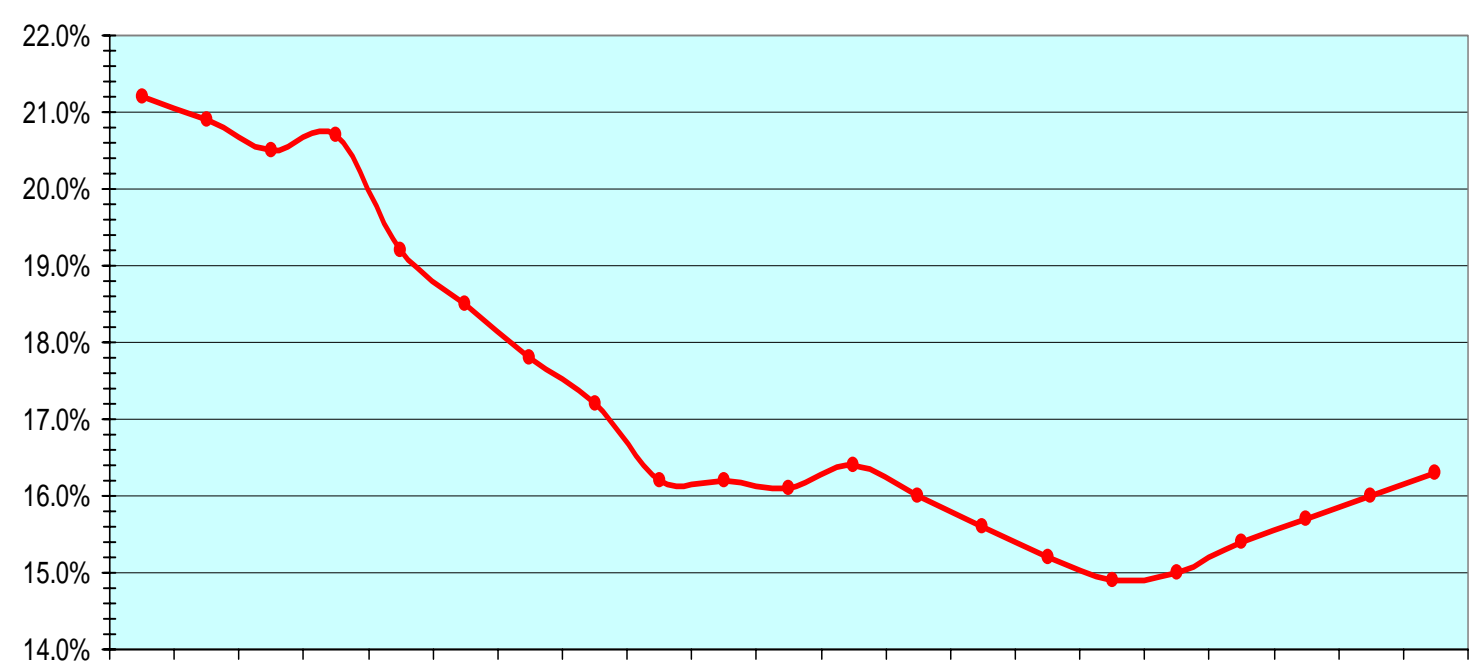

198019811982198319841985198619871988198919901991199219931994199519961997199819992000

Source: White (2001), Table 12

\section{Figure 2: Declining diversification among US manufacturers}

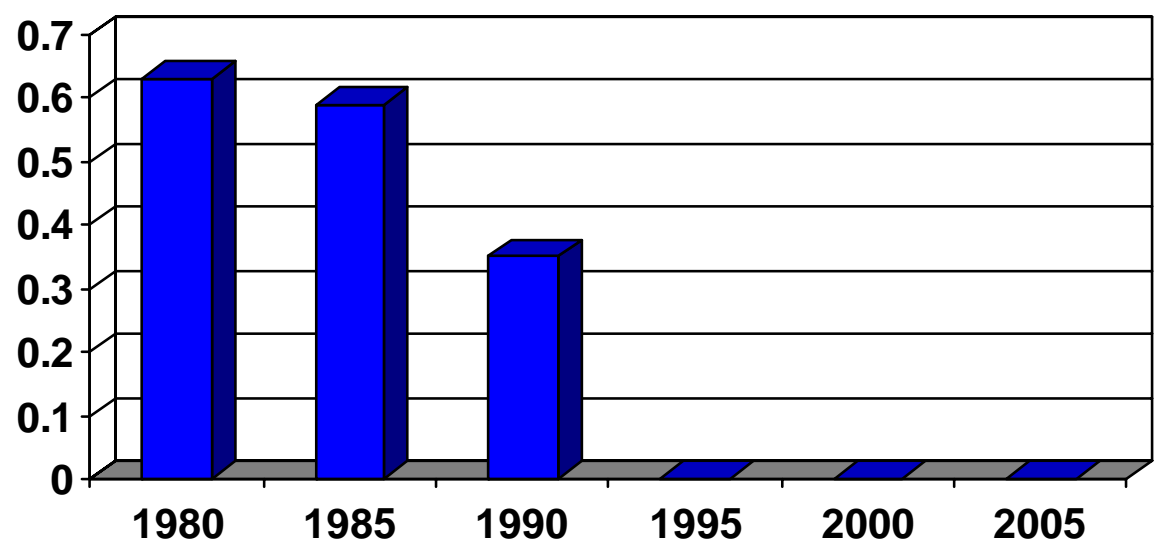

Median industrial diversification among Fortune 500 manufacturers

"Diversification" calculated using the entropy measure of unrelated diversification $\mathrm{DU}=\Sigma \mathrm{P}_{i} \ln \left(1 / \mathrm{P}_{i}\right)$, where $\mathrm{P}_{i}$ is the proportion of a firm's sales made in 2-digit industry segment $i$, as reported on annual 10Ks. Sample is 500 largest manufacturers (by sales) for each year 
Although the dis-integration and narrowing focus of large American firms has been going on since the mid-1980s, the mechanisms by which these transformations were brought about have changed. In the 1980s, the vehicle was primarily hostile takeovers and subsequent breakups of the huge and ultimately unsuccessful (by the judgment of the stock market) conglomerates created during the 1960s and 70s (Davis, Diekmann and Tinsley, 1994). By the 1990s, leveraged buyouts were replaced by spin-offs as firms like GM and Ford, which had once regarded their high degree of vertical integration as a source of competitive strength, now sought to unburden themselves of the high-cost union labor that had become a major competitive burden by spinning off their parts and components operations into separate companies (Delphi in the case of GM, Visteon in Ford's).

Outsourcing, that is, moving a variety of "non-strategic" activities from in-house to outside suppliers, continues to be seen as a major means of decreasing costs and increasing efficiency by a growing number of American corporations. In electronics, firms formerly referred to derisively as "box stuffers" did an increasingly large proportion of manufacturing and distribution for OEMs. Ingram Micro, for instance, assembled PCs for four of the five largest PC “manufacturers" during the late 1990s on the same assembly lines. And, although merger and acquisition activity picked up substantially at the end of the 1990s and continues to grow today, the large majority of such transactions, whether within a single country or across national boundaries, are for the purpose of horizontal rather than vertical expansion or diversification, and to grow the market for existing activities rather than to take on new ones (Aguilera, Dencker, and Escandell, 2005).

While companies are moving parts of their operations from the status of in-house activities to purchased goods and services, they are at the same time forming a variety of close 
relationships with suppliers and partners. Among such arrangements are joint ventures, strategic alliances, and long-term relationships with dedicated suppliers, where purchases are determined by considerations that go well beyond arms-length bidding. In some cases, such suppliers are privy to the proprietary designs of their customers, may share in the design process, and may in some cases actually build their inputs inside the customer's own plant. Volkswagen's famous assembly plant in Resende, Brazil allocated virtually all direct labor to multinational suppliers housed directly on the assembly line, including Rockwell and Cummins from the US, Eisenmann from Germany, and Delga from Brazil. Employees of Volkswagen performed R\&D and exercised quality control over the final, VW-branded products.

Corporate boundaries, in short, are increasingly ambiguous, and with them the locus of corporate responsibility becomes more uncertain.

\subsection{Eroding National Boundaries}

American firms expanded their global reach significantly during the past two decades, in both production and sales. The proportion of sales outside of the United States by the largest US firms (in manufacturing, retail, transportation, and finance) increased from less than 14 percent in 1985 to more than 30 percent in 2001, with only a slight drop in the aftermath of 9/11 (see Figure 3 below). The fact that international trade grew faster than global output, both for the world as a whole and for nine of the ten largest countries (Japan being the lone exception), while foreign direct investment (FDI) grew still more rapidly than both, indicates that the same phenomenon was occurring in other major industrialized countries as well. 
Figure 3: Increasing international sales of large US firms

\section{Percent sales outside US for Fortune largest US firms, 1985-2003}

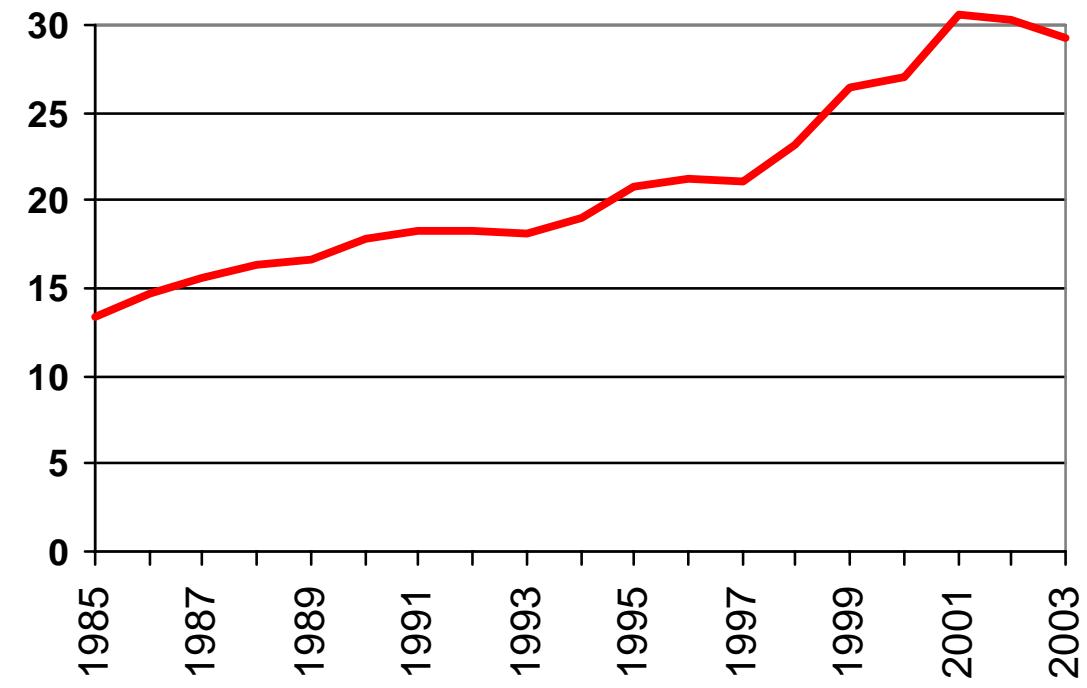

Mean non-US sales calculated from firm-level geographic segment data for the 1986 Fortune 500 largest manufacturers, as reported on annual 10Ks 
American firms had been investing abroad almost since the end of World War II, and European firms had been doing so for centuries. But now FDI was taking on a new and increasingly important aspect: the globalization of production through the creation of a global supply or "value added" chain. No longer could one define unambiguously an "American" car or a "Japanese" machine tool when, increasingly, different pieces of the production chain occurred in more than one country before the final product was assembled in, possibly, yet another one. That this type of globalization has become increasingly significant is attested to by the fact that, in recent years, nearly half of the United States' total imports reflect transactions between different parts of a single firm (A.T. Kearney, Globalization Index, 2003) rather than arms-length sales to final consumers.

Globalization in production and sales has been accompanied by globalization in regulatory jurisdiction, as firms fine-tune their legal homes for tax and other benefits. American firms have long enjoyed "issuer choice" with respect to that state in which they are legally incorporated; it need bear no relation to the locations where they are headquartered or do business. But now such choice has gone global. American firms frequently locate their nominal headquarters or subsidiaries outside the country for tax purposes, while a few multinationals have split their jurisdictional loyalties so many ways as to erase any semblance of national identity. Tommy Hilfiger Corporation in 2001 "had its corporate headquarters in Hong Kong, was legally incorporated in the British Virgin Islands, listed its shares on the New York Stock Exchange, held its annual meeting in Barbados, and contracted to have its products manufactured primarily in Mexico and Asia” (Davis and Zald, 2005: 338). Royal Carribean Cruises is headquartered in Miami and registers its ships in the Bahamas, Ecuador, and Norway but is legally incorporated in Liberia: under Liberian law it is a foreign corporation not subject to 
Liberian income taxes, while the IRS considers income "derived from...the international operation of a ship or ships” by a foreign corporation to be exempt from US income taxes, according to the firm’s 20F. The Liberian corporate registry, in turn, is a business housed in a non-descript office park near Dulles Airport in suburban Vienna, Virginia.

\subsection{Changing Employment Relations}

Changes in the boundaries and locales of firms have produced enormous changes in the character of the employment relation. Whereas at the beginning of the 1970 s a job with a large American firm could generally be regarded as a lifetime commitment, with regular raises and generous benefits upon retirement, thirty years later employment relationships were regarded as contingent and, very often, temporary. As downsizing, restructuring, and outsourcing became increasingly common approaches to cost-cutting, a heightened risk of job loss extended to areas that had previously been relatively immune, including the professional and managerial class. The utilization of temporary employees and contract business services increased significantly and expanded up the scale from low-skilled, low-paid occupations to encompass such professionals as lawyers, accountants, engineers and even business executives (Whitman, 1999).

The United States remains unique today in the flexibility and fluidity of its labor markets. In most other industrialized countries, some combination of more powerful unions, stronger labor-protection legislation, or more deeply-embedded social mores have preserved stable employment relationships. But stability can also imply rigidity, and in a number of continental European nations the protected labor markets and related welfare-state benefits have come under increasing pressure from global competition, budgetary strains, and persistently high levels of unemployment. In France, Germany, and several smaller European nations, firms are downsizing and restructuring in the face of strong political opposition, and the importance of 
part-time and temporary employment has increased. In Japan, the cradle of lifetime employment, change has accelerated under the pressure of prolonged economic stagnation (Ahmadjian and Robinson, 2001). Among the unprecedented measures adopted by a growing number of firms there are short-term employment contracts, layoffs and the encouragement of "voluntary" early retirement, and the substitution of performance-based pay for earnings based strictly on seniority (Whitman, 2000).

\subsection{The Responsibility Paradox}

We have argued that CSR largely arose out of commitments by companies to their employees and to communities where they were located. The "soulful corporation" owed its employees more than a paycheck, and "Its responsibilities to the general public are widespread: leadership in local charitable enterprises, concern with factory architecture and landscaping, provision of support for higher education, and even research in pure science, to name a few" (Kaysen, 1957: 313). But if employees are temporary, and production is contracted out, who is owed a responsibility? What is "local charitable enterprise” for a company such as Tommy Hilfiger-Hong Kong, Barbados, New York, Mexico, or the countless malls where its goods are sold? And what does Royal Carribean Cruises owe to Liberia, its nominal legal home, which few of its executives could locate on a map? As Martin Wolf put it, "The interests of a transnational company are not the same as those of the country from which it originates or of the workers it has historically employed. It has become, to coin a phrase, a 'rootless cosmopolitan'” (2004: 243-4).

When the lines of demarcation between "domestic" and "foreign" and between what is "internal" and "external” to a firm are clear, the assignment of responsibility for behavior, and the jurisdiction that should be looked to for recourse, is generally unambiguous. As the 
transformation of multinational corporations has made these boundaries increasingly fuzzy and permeable in many cases, much of the clarity in assignment of responsibility and jurisdiction of recourse disappears. And these developments have created new and unfamiliar dilemmas for firms and governments alike, dilemmas that both groups are struggling to resolve.

In the days when the boundaries were clear, it would not have occurred to a company that it might be held responsible not only for its own behavior but for the behavior of its suppliers as well, in such sensitive areas as human rights, labor rights, and environmental impact. But beginning with the highly-publicized campaign against Nike by a number of NGOs in the mid1990s based on allegations of labor abuses by suppliers in Southeast Asia, more and more American firms have discovered that the legal boundaries of their firm are no longer a safe haven.

After initial resistance, large firms have attempted to impose standards of behavior on their suppliers and to persuade their critics, with varying degrees of success, that they are sincere in their efforts and that these have led, in many cases, to the elimination of the abuses at issue. Fung, O’Rourke and Sabel (2001) argue that lead firms are increasingly adept at monitoring the quality and production processes of their supply chain and assert that "All of the main garment, shoe, and toy companies—Nike, Reebok, Adidas, Levi’s, Disney, Mattel, the Gap—now have programs in place that combine codes of conduct, in-house assessment, and assistance from third parties to monitor supplier compliance with these codes." Due to growth in demand for thirdparty monitoring, a long and growing list of standards and monitoring organizations and processes have arisen, some as partnerships between firms and NGOs (and, in some cases, with government as well), and others that are strictly within the control of one group or the other, often creating mutual antagonism and suspicion. But figuring out how to deal with this 
expansion of the boundaries of corporate social responsibility remains very much a work in progress.

Even more problematic is the blurring of national jurisdictions where some multinational firms are concerned. In the last few years, several plaintiffs groups have brought suit in the U.S. courts against American firms, of which ExxonMobil and Unocal are the best-known, for alleged complicity with foreign governments in violations of human rights in host countries. As the legal basis for their suits, these plaintiffs have cited an until-recently-obscure $18^{\text {th }}$ century law, the Alien Tort Claims Act, originally intended to facilitate the prosecution of pirates plying their trade on the high seas. The Unocal case was recently settled out of court and the ExxonMobil case is still in litigation. The U.S. government, for its part, has expressed concern about the possible economic and foreign policy implications of holding U.S.-based firms responsible for the reprehensible behavior of governments of some host countries (Myanmar and Nigeria, respectively, in the two instances just cited). And while a growing number of American companies have taken it upon themselves to hold supplier firms abroad to agreed standards of behavior, no firm has indicated its willingness, or ability, to assume similar responsibility for the actions of a sovereign government.

At the same time, firms listed on US stock markets, whether domestic or foreign, are bound by relevant American laws, including the Foreign Corrupt Practices Act of 1977 (intended to limit bribery payments), and Congress has occasionally used securities regulation to sanction foreign governments. The initial draft of the Sudan Peace Act of 2001 included a provision that "No entity that is engaged in any commercial activity in Sudan may trade any of its securities (or depository receipts with respect to its securities) in any capital market in the United States unless that entity has disclosed, in such form as the Securities and Exchange Commission shall 
prescribe - (1) the nature and extent of that commercial activity in Sudan, including any plans for expansion or diversification; (2) the identity of all agencies of the Sudanese Government with which the entity is doing business; (3) the relationship of the commercial activity to any violations of religious freedom and other human rights in Sudan; and (4) the contribution that the proceeds raised in the capital markets in the United States will make to the entity's commercial activity in Sudan.” Although this section did not make it into the final bill, its proposal was sufficient threat to cause NYSE-listed Talisman Energy, a Canadia oil firm, to pull out of Sudan. That same year, the SEC announced new disclosure rules requiring US-listed firms to disclose activities in states subject to US government sanctions, such as Cuba and (at that time) Iraq.

This blurring of boundaries, at the level of both the nation and the firm, has added new complexity to the classic question of the nature of a corporation. Is the modern multinational corporation, with its global reach in both production and sales, an organic entity, a social being with responsibilities, above and beyond simply obeying the law, to all the various stakeholdersemployees, customers, shareholders, creditors, suppliers, communities, even society as a whole — that are impacted by its activities? And if, indeed, it is such an organic center of power, in its global scope not unlike the British Empire of earlier days, how are the scope and limits of its social responsibilities to be defined and implemented? Or is this corporation simply a nexusof-contracts, with residual responsibilities to only one group, its shareholders? From this latter perspective, the concept of "social responsibility", global or otherwise, becomes meaningless as applied to a corporation. Such an entity has, as Baron Thurlow put it, "no soul to damn, no body to kick” (Coffee, 1981). 


\section{Globalization and the Changing Environment for GCSR}

Carl Kaysen (1957) listed stockholders, employees, customers, the general public, and the firm itself as the constituencies owed a responsibility by the management of the corporation. Three major developments during the second half of the twentieth century interacted to change the relations among firms, managers, and these various constituencies. First was the progressive liberalization of cross-border trade in goods and services. Second, economic deregulation and/or privatization in the domestic economies of many countries expanded the domain of the private sector and opened up new opportunities for market competition. Third, rapid advances in information and communications technology not only stretched supply chains in many industries virtually across the globe, as already described, but also created new industries and increased the tradability of many services long thought to be confined by their very nature to a single domestic market.

These developments and the mutually-reinforcing interactions among them have added new dimensions to the classic question about the nature of a corporation and what that implies for the scope of its social responsibilities. It has also intensified competitive pressures in all markets in which firms operate: pressures "from below" in markets for goods and services and pressures "from above" in the markets for financial assets and corporate control. Such pressures were felt earlier and more intensely in the United States than in most other industrialized nations, where a variety of structural and institutional buffers softened and delayed their impact. But by the turn of the century, many of these buffers had been substantially weakened, and the kind of pressures described here for firms in the United States were being felt increasingly by those in other countries as well. 


\subsection{Pressures from Product Markets}

The impact of trade liberalization on competition in product (and, increasingly, services) markets is obvious; the resulting globalization of competition has been a major factor in holding down US and global inflation. The rapid growth of FDI flows from industrialized nations into a number of developing or emerging-market countries, of which China has become the most prominent, has complemented and intensified the impact of trade liberalization. Together, these developments have accelerated the entry of this latter group of nations into global competition in product markets and thus intensified competition for all participants in these markets.

This intensification of product-market competition and the loss of market power experienced by American firms is partly reflected in a decline in concentration ratios, which measure the degree to which a small number of firms dominate a market, and even more dramatically in the almost steady-decade-by-decade decline in the profit margins of these firms, from the 1960's through the end of the century. But the shift in power from producers to consumers may be even greater than these data indicate, because the increase in the quantity and quality of information available to consumers and the speed with which they can access it has created a sort of virtual competition where no actual change need occur in the flow of transactions. Many people who continue to purchase cars from local dealers have found their price-bargaining power substantially enhanced by comparative data gather in advance from the internet. Thus, the oligopoly profits that Kaysen cited as a source of managerial charity have largely evaporated. In a global economy, oligopolies are hard to come by.

\subsection{Pressures from Capital Markets}

The second condition that enabled the expansive responsibilities of the corporation, according to Kaysen, was “managerialism,” that is, a situation of dispersed and relatively powerless shareholders. But as the developments in markets for goods and services were 
creating new pressures from below, developments in US asset markets, including the rapid growth of pension funds, mutual funds, and other institutional investors were generating equally intense pressures from above. Around the middle of the 1970s, the sharp separation of ownership and control that had characterized American-style capitalism for at least half a century began to erode. The proportion of the shares of the nation's thousand largest publicly-held companies held by such large institutional investors rose from just over 15 percent in the mid1960s to over 70 percent in 2005 (see Figure 4 below). As their ownership of corporate America grew, these investors exercised their new power in a variety of ways. In particular, they played a major role in the development of a market for corporate control that emerged during the 1980s (Davis and Thompson, 1994).

Figure 4: Increasing corporate ownership by institutional investors

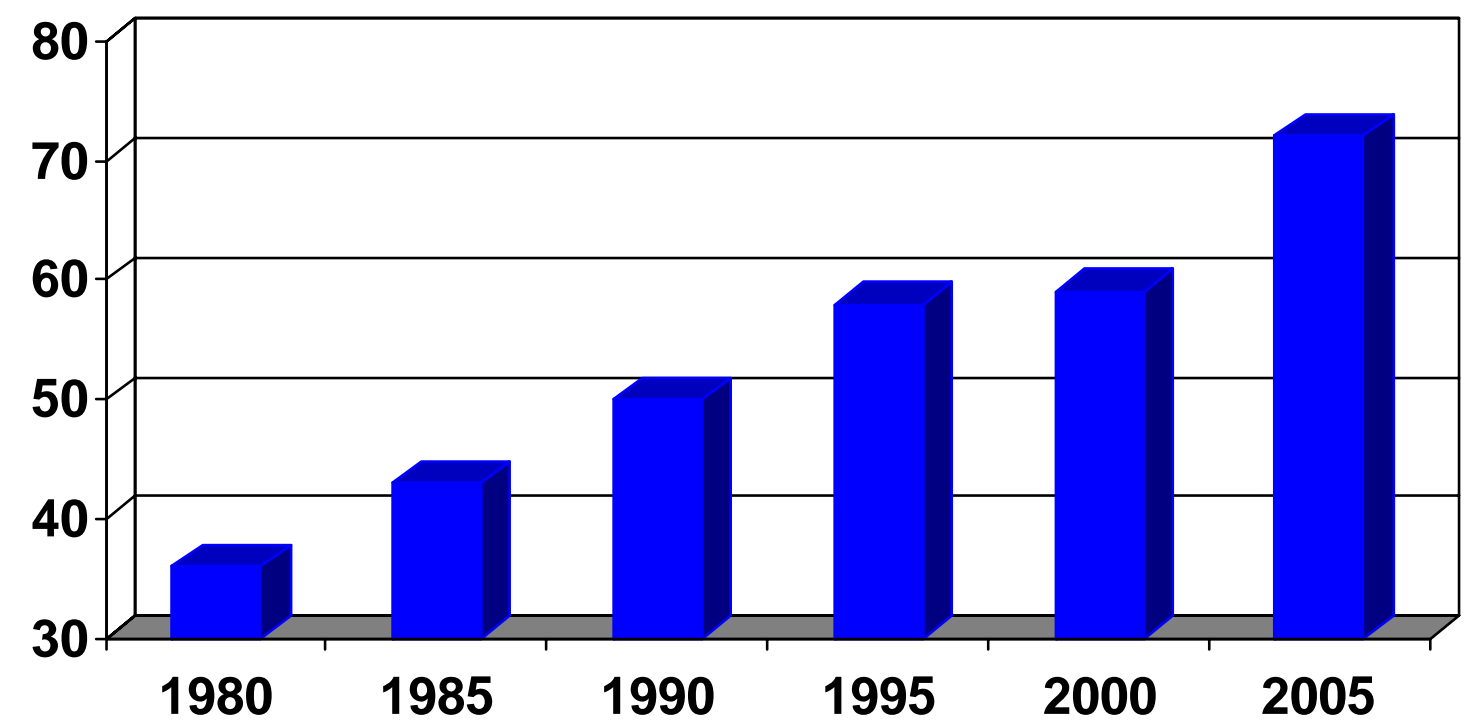

Mean ownership by institutional investors of 1000 largest corporations (From Spectrum database of $13 \mathrm{~F}$ institutional ownership filings, various years) 
Frustrated by these developments and empowered by economic deregulation and a more relaxed anti-trust environment, financial innovators sought new ways of wringing improved financial performance from companies that had grown complacent and unfocused. The result was an unprecedented wave of mergers, breakups, hostile takeovers, and leveraged buyouts in the 1980s. Mergers and acquisitions of publicly-traded companies more than doubled between 1980 and 1988 and then, after a pause, tripled again between 1990 and 1998 (White, 2001). Executives of companies with disappointing earnings or sagging stock prices, and even of companies that were doing well, felt their positions threatened along with the very survival of their firms (Whitman, 1999).

The threats these executives perceived were real. One-third of the 1980 Fortune 500 disappeared through merger during the 1980s, and by 2000 roughly two-thirds of the 1980 group had dropped off the list. And the job security of the chief executives of such companies, a position long thought of as a virtually bullet-proof sinecure once it was achieved, was shattered by a boardroom revolution that greatly increased levels of top executive turnover (Whitman, 1999). Moreover, a growing share of executive pay came in forms such as stock and stock options that were contingent on their firm's financial performance and, above all, on the price of its shares. Senior executives responded, unsurprisingly, with an intensified focus on increasing profits and obtaining higher price/earnings ratios. In extreme cases, these developments produced the earnings manipulation and outright fraud that, combined with the explosion of executive compensation, undermined public trust in business and produced corrective responses on the part of government, in the form of the Sarbanes-Oxley legislation and the associated changes in regulations by the SEC and the New York Stock Exchange (Whitman, 2003). 
As in the case of intensified competitive pressures in product markets, increasing international integration of asset markets has also served to spread capital market pressures to firms in other industrialized countries through several channels. One is the rapid increase in the number of non-U.S. firms listed on Nasdaq and the New York Stock Exchange. By 2005, all but two of the world's 25 largest corporations were listed on the NYSE (the exceptions being Germany's Volkswagen and France's Carrefour), and there were more foreign firms listed on US markets than there were German firms listed on the Deutsche Borse. As we noted previously, such firms must meet all the rules of the exchange on which they are listed as well as US securities regulations. There is anecdotal evidence that the more onerous demands imposed by Sarbanes Oxley may have slowed this process, and may even lead some foreign firms to de-list, but so far there has been more grumbling than action, as the allure of the world's largest capital market is difficult to avoid. Indeed, the SEC's 2004 actions against Royal Dutch/Shell, Mexico’s TV Azteca, Italy’s Parmalat, Dutch Ahold, and France’s Vivendi-Universal led some Europeans to refer to "US regulatory imperialism” (Wall Street Journal, July 30, 2004).

At the same time, other industrialized nations are responding to similar pressures for higher standards of corporate accountability and a greater stress on the governance role of truly independent “outside” directors. American institutional investors have, for example, brought their bottom-line focus with them into the European marketplace. In addition, they have led by example, as domestic pension funds, mutual funds, and other intermediaries have begun to emulate the shareholder activism of their American counterparts. This shift away from the patient capital provided by banks committed to long-term relations with their customers toward much more demanding sources of funding has been forcing firms to pay more attention to good governance, accountability, and profitability. 
All these developments in capital markets have been facilitated and reinforced by legislative and regulatory moves, at both the national and the EU levels, to tighten accounting standards, criminalize insider dealing, dismantle restrictive voting structures, and legitimize takeovers. And privatization of formerly state-owned firms in Germany, France, and other European nations is also forcing managements and boards to pay more attention to profitability and shareholder returns. In Japan, depressed stock prices and declining dividends are forcing many companies to reduce cross-holdings of shares, and the importance of the "main banks" that had been the principal suppliers of credit to non-financial corporations has declined. Similarly, the importance of cross-shareholding ties between large companies and their suppliers and customers has been declining as the prolonged recession has encouraged diversification of such business relationships. Indeed, a number of large Japanese firms, among which Nissan and Mazda are perhaps the most prominent, have been forced to accept what was previously unthinkable: controlling ownership by a foreign investor, accompanied by a new management focus on the bottom line.

One result of the global spread of capital market pressures is that the American boardroom revolution of the 1990s appears to be going global. We earlier noted increased turnover of CEOs in the United States. A study of the world's 2500 largest listed companies by the consulting firm Booz Allen Hamilton revealed that the number of chief executives dismissed worldwide rose significantly in 2002, increasing from 2.3 percent in 2001 to 3.9 percent in 2002, as compared with only 1 percent in 1995. That board and shareholder impatience with poor financial performance underlay these dismissals worldwide is indicated by the fact companies where chief executives were dismissed generated total shareholder returns 6.2 percentage points lower than companies whose CEOs retired voluntarily. 


\subsection{Pressures from the Polity}

In addition to product and capital market pressures, multinational corporations faced political pressures arising out of the process of globalization itself. International trade and crossborder investment flows increased with economic reform in China and India, and the break-up of the Soviet Union brought a whole new set of countries into the orbit of the world capitalist system. A neo-liberal ideology emerged that called for an opening of borders to capital flow and lowering the barriers to foreign investment. International agencies such as the World Bank and the International Monetary Fund that existed to promote development increasingly included the extent to which an applicant was moving in the directions suggested by neo-liberalism as part of the criteria for granting loans or development funds.

Part of neo-liberal doctrine entails the opening of national markets not only to investment, but also to product competition. Even if a country operated with an extensive market system, a long tradition of tariffs and other forms of trade protection often protected local products from lower cost goods from elsewhere. Such an opening creates local disruption and instability_both in the industries in countries losing jobs to lower cost nations and in the countries whose home industries are exposed to lower cost products. As doctrines of free trade became institutionalized in international agreements, in the demands of international economic agencies, and in national policies, negative reactions to neo-liberalism grew. Moreover, a number of social movements that seemed to be only the reflection of internal conflicts began to show a transnational aspect.

Multinationals were often the target of local and, eventually, global social movements. One of the first global social movements was aimed at Nestle's marketing of infant formula in low-income nations of the global south. European NGOs argued that Nestle's marketing efforts were unethical: mother's milk is more healthful than formula, and consumers often used unclean 
water to mix the formula, or diluted it with too much water due to the cost, resulting in disease or malnutrition for their infants. Nestle's inaction in response prompted the Infant Formula Action Coalition (INFACT) to call an international boycot of Nestle in 1977, resulting in US Senate hearings and the development of a UNICEF/World Health Organization code for marketing infant formula in 1981, which prohibited advertising, promotion, and providing samples. The boycott ended in 1984 when Nestle agreed to abide by the new code (Van Alstyne, 2005). The Nestle boycott became a model for subsequent global consumer boycotts.

Indigenous peoples' movements in low-income countries began to forge links to supportive organizations in the wealthier global North. In the early 1990s, the Ogoni people of Nigeria began a series of protests against Shell and the Nigerian National Petroleum Corporation. The environmental impact of Shell's operations in Nigeria, and the minimal economic benefits to the indigenous people around those operations, prompted large-scale protests at Shell facilities, which temporarily halted oil extraction in the Ogoni land 1993. The brutal response of the Nigerian military resulted in the destruction of over three dozen villages and the arrest and execution of nine Ogoni protest leaders. Global social movements joined in support of the Ogoni, launching an international boycott of Shell and a shareholder campaign among some of Shell’s institutional investors (Van Alstyne, 2005).

In the mid-1990s the student anti-sweatshop movement mobilized and spread across the United States. Moreover, labor unions saw their jobs going overseas and began to take a large interest in job flight and the location of plants overseas. Indeed, the student movement grew out of activities originally sponsored by the AFL-CIO. The major role of unions in the antisweatshop movement has reinforced the suspicion of many developing countries that this movement is a thinly-disguised form of advanced-country protectionism. An ingenious program 
for eliminating the protectionist character of universal standards by conditioning them on a country's level of development, while at the same time introducing the concept of continuous improvement in such standards, has been advanced by Fung et. al. (2001).

In each of these cases, the activities of global corporations could be challenged. "Brands" were both the target and the rationale for some movements, e.g., against Nike and the Gap. The environmental and native rights social movement organizations (SMO) charged that companies extracting metals and fossil fuels often despoiled the environment in LDCs. Human rights organizations joined the anti-sweatshop movement and labor unions in attacking the labor practices of global corporations - the use of child labor, the poor working and living conditions provided, the inadequate salaries.

Beginning with demonstrations against the negotiations over NAFTA, loosely coordinated anti-globalization demonstrations were mounted, usually connected to the meetings of international organizations and leaders of developed countries participating in negotiations over international financial and trade arrangements. Often the demonstrations took place in several countries over the same short time period, (e.g., demonstrations of two days to a week). Although these demonstrations were sometimes seen as a single global justice movement, it needs to be remembered that they were essentially transient teams of SMOs and activists from a number of somewhat disparate movements, labor unions, and church groups (Davis and Zald, 2005). From 1999 until 2001, anti-globalization demonstrations could be seen as the major set of collective actions drawing attention in the mass media and forcing social responsibility issues of the global corporations onto the public agenda. At the same time, institutional investors expanded their corporate responsibility agenda to include global issues (Proffitt and Spicer, 2003). 
While social movement pressures on multinationals have become increasingly globalized, regulatory pressures from governments have also been going global. This development is particularly evident in the increasingly global reach of the European Union (EU) regulations regarding both the characteristics of the goods and services that are internationally traded and the processes by which they are produced. The reason is that, where protection of consumers or of the environment is concerned, EU requirements are generally more stringent than those of the United States or of most other nations. This stringency is grounded in the EU's strong adherence to the "precautionary principle" which holds that, in cases where there is uncertainty regarding the possibility of harm, rules and standards should err on the side of caution.

The EU has not always prevailed when specific applications of the precautionary principle have been submitted to the WTO's dispute-settlement procedures, whose sanction is necessary for a provision to be incorporated into the formal body of supranational law. But its record in creating de facto global law is more impressive. With the recent addition of 10 new members, the EU's 25 nations together constitute the world's largest market—surpassing the United States—and non-EU companies that compete in the global marketplace, or hope to do so, are increasingly designing and manufacturing their products to conform to EU requirements. That is because customizing products to meet different rules and standards in different countries would vastly increase complexity and expense; uniformity requires that the most rigorous regulations and standards will prevail.

Thus it is that that a wide and growing variety of consumer products made by firms based outside the EU have been or soon will be adapted to meet EU safety, environmental, and recycling rules. As Jeffrey Immelt, CEO of GE, put it: “Europe is in many ways the global regulatory superpower. It can speak with one voice and a degree of certainty.” An EU ban on 
lead, cadmium, and mercury in electronic products beginning in 2006 is forcing the global electronics industry to drive out their use throughout their supply chain, affecting thousands of firms around the world. Requirements for producers to be responsible for subsequent recycling their own products led Dell to change the designs of its computers for easier dis-assembly, and it now offers free pickup and recycling of its computers in both Europe and the US (Gunther, 2005). European pressures also influence the processes involved in international commerce. For example, over the past few years, some 200 U.S. companies, including Microsoft, have signed "voluntary" agreements to abide by EU privacy rules, which affect the transfer and use of online data about individuals and thus have an impact on virtually every firm that has workers, suppliers, or customers within its borders.

Perhaps the greatest impact of EU application of the precautionary principle is on farmers, primarily but not exclusively American, who make use of biotechnology in producing genetically modified crops. Because of stringent EU restrictions and labeling requirements on genetically altered foods or ingredients, multinational food processors are increasingly refusing to buy them on the grounds that they are likely to cause marketing problems in Europe. The global reach of such decisions is broad indeed: it has been alleged that food-scarce African nations are avoiding growing food from better-yielding genetically modified seeds for fear that such crops would not be exportable to EU countries.

The European Union has also promoted standards on environmental policy that affect all corporations doing in business in Europe. Even though the United States has not signed on to the Kyoto Treaty, the fact that it might become internationally adopted without the United States, has led companies to adopt policies in accord with its requirements even before it actually received the required number of national commitments in 2004 (Hoffman, 2005). 


\section{Corporate Responses to Global Pressures}

Global corporations in the $21^{\text {st }}$ century face a number of colliding forces in product markets, capital markets, and in the polities where they operate. Product market competition, along with lowered trade barriers and advances in ICTs, have led to the elaboration of global supply chains, sourcing high value-added steps to advanced economies and outsourcing low value-added steps to developing economies with lower wages and labor standards. On the other hand, quality standards for durable goods increasingly compel the adoption of a Toyota-like production system around the world. And the EU's standards, including the precautionary principle, increasingly bind companies to strict requirements for consumer goods—at least those companies that hope to sell in the world's largest consumer market. For investors, the American standard of corporate governance, with its focus on shareholder value, prevails for the largest firms, demanding strict attentiveness to profitability. And both social movements and regulators are increasingly trans-national in their scope: scrutiny of labor and environmental practices around the world can generate organized international responses, such as protests and boycotts of consumer goods. Moreover, firms are increasingly held responsible for supply chains from endto-end, including suppliers and governments of the nations where they operate.

What patterns have emerged in the responses of multinationals to this array of new pressures when it comes to social responsibility? The initial response entailed the growth of social-responsibility reporting, both in annual reports or special reports by individual firms (beginning in 1972 with General Motors' Public Interest Report) and, more recently, by industry groups. Both the comparability and the credibility of such reporting is enhanced by the emergence of independent organizations organized to carry it out on a global scale. In the environmental arena, these include ISO 14000 environmental standards and the Global Reporting 
Initiative. In CSR, a number of competing standards and ratings agencies have arisen, but we suspect that a common standard will emerge.

The European Commission has the most experience at harmonizing cross-national standardsfor CSR, and a number of European companies (and American subsidiaries in Europe) have multi-national works councils where employee and management representatives engage issues such as restruturing and CSR. Although these practices are generally not exported across the Atlantic to the US, an important exception was DaimlerChrysler, whose World Employee Committee included members from six countries, and whose firs task was to construct with management a set of guiding principles for global corporate responsibility (Kristensen and Zeitlin , 2005: 292-3). Fung et al. (2001) propose a self-regulatory "race to the top" that will both promote voluntary adoption of the highest standards by firms and the creation of best practices and credible certification by outside monitors.

Many of America's leading corporations have adapted their organizational structures by establishing a public-policy or social-responsibility committee of the board of directors and/or an environmental or HES (Health, Environment, Safety) staff headed by a vice president or other corporate officer, whose job it is to develop and implement effective programs not only to meet but, in many cases to go beyond, regulatory requirements. And, as the largest American firms increasingly organize their design, purchasing, production, and marketing strategies on a global basis, they are beginning to standardize their social-responsibility activities globally as well. Within the constraints imposed by differing national regulations, more and more leading firms are developing internal HES standards and control and audit procedures for their products, plants, and processes worldwide. Such an approach not only yields the cost reductions associated with standardization, but also makes employee training and communication more 
effective and encourages the dissemination of best practices throughout the company's operations.

The implication of global firms' adoptions of standards for HES and for social responsibility can be broad. Global firms provide a mechanism for the spread of standards around the world, both within their own corporate boundaries and among their suppliers and other contractors. Thus, Ford's program for addressing HIV/AIDS among employees in its South African assembly plants were subsequently implemented in its facilities in China and India, transferred via the corporate health and safety department. It also provided a benchmark for programs of other, competing employers, as well as for Ford suppliers. Just as foreignowned plants are argued to raise prevailing wages in the communities where they are located, they can also raise labor and environmental standards and norms for social responsibility.

It is possible, of course, that we overestimate the capacity of MNCs to spread practices effectively within their own boundaries, much less to suppliers or other firms. Kristensen and Zeitlin (2005) analyze a London-based multinational that, like most MNCs today, achieved most of its growth through acquisitions around the world. Acquired firms responded in a variety of ways to their new corporate parent, but most maintained a substantial heritage of prior practice and ties to their local communities, and few became simply clones of a global model. Moreover, they found that the attention of corporate executives in London was much more oriented toward peers at other firms and the financial community and less on the operations of their firm on the ground in Denmark or Wisconsin. MNCs, in this view, are best seen as webs of semiindependent firms linked in a quasi-market, rather than coherent hierarchies in which the top commands and the bottom obeys. Our expectation, however, is that such arrangements are relatively short-lived, and that over time standardization on certain principles will out. George 
David, CEO of United Technologies—a global manufacturing conglomerate that grew through a vigorous acquisition program—states that "we tolerate zero variance anywhere in the world from our global [health and safety] standards. Since these are typically set off US law and regulation, we end up exporting US practices all over the world” (Speech before the Council on Foreign Relations, March 15, 2000). Our experience suggests this is the more typical course.

Our analysis suggests that GCSR will increasingly be formally and materially supported in the policies and practices of corporation, whether or not top management has an ideological commitment to the policies. Global corporations now exist in a matrix of norms, organizational interests, and institutional structures that they cannot ignore. But what standards are likely to prevail? On the one hand, multinationals are devoting increased attention, in terms of money as well as executive time and attention, to CSR on a global scale, while at the same time exploiting jurisdictional freedom to minimize labor or environmental costs or tax bills in ways that many would regard as anti-social, in order to meet demands of investors for profitability. The divergent approaches to labor market flexibility in Europe as EU integration increases argue against a simple trajectory.

The overall proposition that emerges from our discussion is that social and regulatory pressures are drivers of GCSR, but that cost-driven processes of standardization within companies will tend to lead the tightest standards to prevail. That is, while production may be organized along Toyota lines, and corporate governance will reflect an American-style orientation to transparency and shareholder value, CSR in multinational firms will follow EU standards. Requirements for product safety and environmental impact that prevail in Europe will be adopted globally, potentially driving a "race to the top." 
We want to place this speculation in the broader debates around globalization. Scholars have sought to find a discernible path in globalization that often seems elusive. Many have deduced a race to the bottom in labor and environmental standards, in which producers chase the lowest-cost labor housed in the most lax regulatory environment, thus inducing states to compete to provide a docile and union free labor force and an anything-goes approach to pollution. Others have argued that a quest for shareholder value and industry dominance leads global corporations to list their shares in the US and thus conform to tight standards of transparency and accountability in corporate governance in order to raise capital (e.g., Coffee, 1999).

The evidence for both is hardly conclusive, and thus we are cautious in adding another "race" to the program. But we find that a combination of factors suggests that global firms will come to conform to EU standards of social responsibility as regards products and processes. First, regulation is the most consistent and effective force favoring CSR. The companies with the best records in particular domains of CSR have tended to be those that are most heavily regulated in those domains. Second, cost pressures typically favor global standardization within corporations, from parts to human resource practices to approaches to CSR. Third, the EU is now the world's largest consumer market, and its environmental and product-safety standards tend to be the strictest; thus, firms seeking to sell their goods in Europe will tend to adopt EU standards on a corporate basis. And finally, research suggests that global firms spread their standards outside their corporate boundaries, either unwittingly, by setting examples for local competitors, or by evangelism of suppliers and partners. Ironically, then, globalization is accompanied both by a race for lowest production costs and increasing demands for corporate social responsibility. In sum, pressures for global convergence of CSR standards are strong, but the paths by which this process proceeds are neither linear nor smooth. 


\section{References}

Aguilera, R.V., J.C. Dencker,and X. Excandell, 2005, "Left at the Alter? A Relational View of Merger and Acquisition Announcements in the 1990s.” Unpublished, University of Illinois Urbana-Champaign, College of Business.

Ahmadjian, C.L, and P. Robinson, 2001, "Safety in Numbers: Downsizing and the Deinstitutionalization of Permanent Employment in Japan,” Administrative Science Quarterly, 46, 622-654.

Coffee, J.C., Jr., 1981, “No Soul to Damn, No Body to Kick: An Unscandalized Enquiry into the Problem of Corporate Punishment,” Michigan Law Review, 79.

Coffee, J.C., Jr., 1999, “The Future as History: The Prospects for Global Convergence in Corporate Governance and its Implications,” Northwestern University Law Review, 93, 641-720.

Davis, G.F., K.A. Diekmann, and C.H. Tinsley, 1994, “The Decline and Fall of the Conglomerate Firm in the 1980s: The Deinstitutionalization of an Organizational Form,” American Sociological Review, 59,547-570.

Davis, G.F. and T.A. Thompson, 1994, “A Social Movement Perspective on Corporate Control,” Administrative Science Quarterly, 39, 141-173.

Davis, G.F. and M.N. Zald, 2005, "Social Change, Social Theory, and the Convergence of Movements and Organizations,” G.F. Davis, D. McAdam, W.R. Scott, and M.N. Zald, eds., Social Movements and Organization Theory, New York: Cambridge University Press, 335-350.

Dobbin, F. and J.R. Sutton, 1998, "The Strength of a Weak State: The Rights Revolution and the Rise of Human Resources Management Divisions,” American Journal of Sociology, 104, 441-476.

Fung, A., D. O’Rourke, and C. Sabel, 2001, “Realizing Labor Standards: How Transparency, Competition, an Sanctions could Improve Working Conditions Worldwide,” Boston Review (accessed on-line).

Gunther, M., 2005, “Cops of the Global Village,” Fortune (June 27), 158-162.

Hoffman, A.J., 2005, “Climate Change Strategy: The Business Logic behind Voluntary Greenhouse Gas Reductions,” California Management Review, 47(3), 21-46.

Jacoby, S.M., 1997, Modern Manors: Welfare Capitalism Since the New Deal, Princeton: Princeton University Press. 
Kaysen, C., 1957, “The Social Significance of the Modern Corporation,” American Economic Review (Papers and Proceedings), 47(2), 311-319.

Kristensen, P.H. and J. Zeitlin, 2005, Local Players in GlobalGames: The Strategic Constitution of a Multinational Corporation, New York: Oxford University Press.

Margolis, J.D. and J.P. Walsh, 2003, "Misery Loves Companies: Rethinking Social Initiatives by Business,” Administrative Science Quarterly, 48, 265-305.

Pollard, S., 1965, The Genesis of Modern Management: A Study of the Industrial Revolution in Great Britain, London: Edward Arnold

Proffitt, W.T., Jr., 2001, The Evolution of Institutional Investor Identity: Social Mobilization in the Shareholder Activism Field, Unpublished Dissertation, Northwestern University.

Proffitt, W.T., Jr. and A.S. Spicer, 2003, Shaping the Agenda of Shareholder Activism: Institutional Investors and Global Corporate Social Responsibility. Working Paper. Riverside, Cal: Graduate School of Management, University of California, Riverside.

Van Alstyne, A., 2005, "Global Social Movements and Global Corporate Social Responsibility.” Unpublished, Sociology Department, Universitiy of Michigan.

White, L.J., 2001, "What's Been Happening to Aggregate Concentration in the United States? (And Should We Care?)," Unpublished, New York University Department of Economics.

Whitman, M.v.N., 1999, New World, New Rules: The Changing Role of the American Corporation, Boston: Harvard Business School Press.

Whitman, M.v.N., 2000, The Evolving Corporation: Global Imperatives and National Responses, Washington, D.C.: Group of Thirty.

Whitman, M.v.N., 2003, American Capitalism and Global Convergence, Washington, D.C.: Group of Thirty.

Wolf, M., 2004, Why Globalization Works, New Haven: Yale University Press. 


\section{Endnotes}

${ }^{* i}$ There are at least as many definitions of CSR as there are writers on the topic - the US Congressional Human Rights Caucus defines it as “achieving commercial success in ways that honor ethical values and respect people, communities, and the environment,” while the European Commission defines it as “a concept whereby companies integrate social and environmental concerns in their business operations and in their interaction with their stakeholders on a voluntary basis.” As we argue in this paper, the "voluntary” aspect can be somewhat ambiguous.

ii The outlier on most of these dimensions is an athletic wear company-Nike-which adopted its stance on labor standards throughout its global supply chain in response to outside pressure from social movements (Fung, O’Rourke, and Sabel, 2001). 